\title{
The Corporate Governance Effect on Financial Performance
}

\author{
Anggit Riyadi ${ }^{1}$ \\ ${ }^{1}$ Department of Accounting-Economic Faculty-Universitas Islam Batik Surakarta-Indonesia \\ Kartika Hendra Titisari ${ }^{2}$, Purnama Siddi ${ }^{3}$ \\ ${ }^{2}$ Department of Accounting-Economic Faculty-Universitas Islam Batik Surakarta-Indonesia; \\ ${ }^{3}$ Department of Accounting-Economic Faculty-Universitas Islam Batik Surakarta-Indonesia;
}

Correspondence : riyadianggit@gmail.com

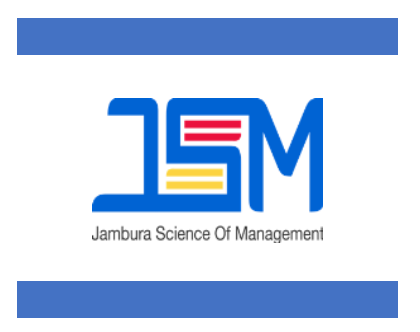

JSM

Volume 3

Number 2

July 2021.

Received on 17 July 2020

Revised on 23 July 2020

Accepted on 28 July 2020

The journal allows the

authors to hold the copyright

without restrictions and

allow the authors to retain

publishing rights without

restrictions. Authors retain

copyright and grant the

journal right of first

publication with the work

simultaneously licensed

under a creative commons

attribution 4.0 international

license.

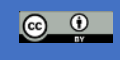

DOI: 10.37479

\section{ABSTRACT}

Purpose: This study aims to examine corporate governance effecton the financial performance of manufacturing companies in the food and beverage industry sector in the Indonesia Stock Exchange in 2014 - 2018.

Design/Methodology/Approarch: The independent variables in this study are the audit committee, the board of commissioners, the board of directors, and debt to equity ratio (DER). Whereas the dependent variable in this test is Return on Equity (ROE). The sampling technique is done by using purposive sampling method, namely the determination of sampling with certain considerations. Data analysis techniques include (1) Descriptive Statistics (2) Classical Assumption Tests covering Normality, Multicollinearity, Heteroscedasticity, and Autocorrelation (3) Multiple Linear Regression Tests (4) F Tests (5) Hypothesis Tests (6) Determinant Coefficient Test (R2). The sample used in this test is manufacturing companies in the food and beverage industry sector which were listed on the Indonesia Stock Exchange in 2014 - 2018, with a total of 10 companies and there were 50 samples that met the criteria.

Findings: The results of this test concluded that the variables of the board of directors and debt to equity ratio (DER) affect financial performance, while the variables of the audit committee and the board of commissioners have no effect on financial performance.

Keywords: Corporate Governance; Corporate Financial Performance; Manufacturing

\section{INTRODUCTION}

Indonesia's growing economy led to a passion for entrepreneurs to manage their company in Indonesia. Competition of food consumption goods and drinks increasingly longer becomes increasingly stringent since the World Trade Organization has been denied. With the formation of the World Trade Organization (WTO) in 1994 World markets tend to be increasingly open and barrier-free (Riyadi, 2012). For that industrial company food and beverage 
consumption goods in Indonesia require additional funding to maintain the company's viability, as well as able to compete with foreign products.

Corporate Governance refers to the rules, processes, and laws in which the company is operated, controlled, and regulated. This explains the rights and responsibilities of corporate participants such as shareholders, directors, officers and managers, and other stakeholders, as well as the rules and procedures for making company decisions. Gitman \& Zutter, (2012) The well-defined corporate governance structure is intended to benefit all company stakeholders by ensuring that the company is executed in a legitimate and ethical manner, according to best practices, and is subject to all company regulations. To realize the performance of a good company in order to increase the value of the company must occur cooperation relationship that is aligned between the management of the company with other parties that include shareholder and stakeholders in making financial decisions with the goal of maximizing the working capital owned.

Return on equity (ROE) is the company's ability to generate profits by using its own capital. The higher the ROE ratio, the better the capital productivity itself in obtaining profit after tax. This ratio is influenced by the big small debt of the company, if the proportion of debt is getting bigger then this ratio will be greater with the assumption that the results of the company's investment is greater than the debt cost.

The establishment of the Board of Commissioners is one of the mechanisms used to monitor managers ' performance. Decree of the board of directors of Jakarta Stock Exchange number: KEP315/BEJ/06-2000 requires companies listed on the stock exchange to have a board of commissioners that monitors the company to create good corporate governance in Indonesia. Hardikasari, (2011) stated that research on the size of the board of commissioners to the performance of the company has mixed results.

In order to monitor the internal control of the bank, the directors have the responsibility to establish policies, strategies and internal control procedures; Implementing policies and strategies approved by the board of commissioners; maintaining an organizational structure; ensure that delegation of authority runs effectively which is backed by the application of consistent accountability and monitors the adequacy and effectiveness of internal control systems.

Debt to equity ratio (DER) is measured by comparing the magnitude of use of debt to own capital owned by the company. This ratio illustrates to the extent to which the owner's capital can cover the debts to outside parties. The smaller the ratio will be better. For the best outside party safety ratio if the amount of capital is greater than the amount of debt or at least equal. But for shareholders or ratio management it should be great.

P-ISSN: 2655-3651 E-ISSN: 2656-0435

P a g e 62 
Research on good corporate governance relations and performance of the company has been carried out, both research using corporate governance assessment index and corporate governance structure. Darmawati et al., (2005) examined the relationship between corporate governance and corporate performance. The purpose of the implementation of good corporate governance is to create and provide added value for all stakeholders sustainably over a long period of time, namely through the increase in management performance to increase the value of the company. The existence of good corporate governance is believed to be a necessity that can bridge the investor's party with the management of the company.

The object of this research is the company of food and beverges because in the sector of consumption industry with its sub sectors, the sub-sector of food and beverages (food and beverage) is one of the sectors that have quite variative growth. The central statistical body of the official website stated that "the growth of production of large and medium manufacturing industries in the period 2014 increased by 4.74 percent compared with the period 2013.

The main cause of the increase is due to the rise of 10.56 percent of food industry production. The reason researchers choose the research object using the company food and beverages is because the company of food and beverages has non-cyclical properties. Non cyclical means that the growth of the industrial sector is more stable and not easily affected by the change of the economic condition or in other words, the smoothness of the food and beverages company will still be assured because this sector is engaged in the field of human staple industry.

Research on the influence of financial performance in this return on asset against the value of the company shows inconsistent results. Return on assets positive shows that of the total assets used to operate, the company is able to provide profit for the company. Conversely if the negative return on asset indicates that the company is experiencing losses. The higher the return on asset shows the better the performance of the company, because the funds invested into the asset can result in an increasingly higher earning after tax (EAT). However, different results gained by Suranta \& Merdistuti, (2004) in his research found that return on assets (ROA) actually negatively impacted the company's value. This indicates that there are other factors that also affect return on assets (ROA) relationships with the company's value. good corporate governance $(\mathrm{GCG})$ as a moderate variable that is suspected of strengthening or weakening the influence.

The results of the research of Homaidi et al., (2019) on the financial performance of the hospitality companies listed on the Bombay Stock Exchange in India for the period 2014 to 2016 indicate that the board size, board of trustees, audit committee size, and institutional ownership have a significant impact on return on asset, while the board composition, audit committee composition, Persistence of the 
audit committee and the company's Later in Garini's study (2014), stating that there was no positive impact on corporate governance and return on asset using the board of commissioners and board of directors as independent variables. The results of the research of Homaidi et al., (2019) on the financial performance of the hospitality companies listed on the Bombay Stock Exchange in India for the period 2014 to 2016 indicate that the board size, board of trustees, audit committee size, and institutional ownership have a significant impact on return on asset, while the board composition, audit committee composition, persistence of the audit committee and the company's. Later in Garini's study (2014), stating that there was no positive impact on corporate governance and return on asset using the board of commissioners and board of directors as independent variables.

Nur \& Tirta, (2011) conducted research on Bank Indonesia that the results of this research showed that good corporate governance has an effect on the financial performance proscribed with return on asset and return on equity. This indicates that the implementation of good corporate governance by Bank Indonesia in commercial banks can reduce conflicts of interest and foster Sharia banking performance, especially in hopes of attracting investors to increase their investments.

Research by Dzingai \& Fakoya, (2017) in Johannesburg can be said that board size and independence of the board is an important factor that affects the company's performance. The size of the board is influential and the company should monitor it effectively. The independence of the Board is also important for the proper functioning and profitability of the company in line with King IV's recommendation for the company to incorporate more independent non-executive directors on board for efficient monitoring and transparency. Results show that mining companies in South Africa adhere to the requirements of the King IV Governance rules.

Fuenzalida et al., (2013) a study examining whether good corporate governance practices resulted in returns for companies in the Lima Stock Exchange (LSE) in Peru showed that investors appreciated the implementation of good corporate governance practices by the LSElisted companies. Their study concluded that there was an incentive for money changers in Peru, which added a company with good corporate governance to their equity portfolios.

Munisi \& Randøy, (2013) a study examining public companies in Sub-Saharan African countries that have adopted good corporate governance practices and their influence on corporate financial performance and market valuation, found companies that adhere to good corporate governance practices to achieve higher financial performance. Unlike the research conducted by Uchida et al., (2011) Examining the relationship between corporate governance and the financial performance of Bangladesh companies with the results 
showed that corporate governance has an insignificant positive relationship with the company's performance. Adekunle \& Aghedo, (2014) Learn the relationship between corporate governance characteristics and corporate financial performance in Nigeria, they have revealed that there is a positive but also significant relationship between members of the board composition and council size as independent variables and company performance. CEO Status also has a positive relationship with the company's performance. However, the ownership concentration has a negative association with return on asset but a positive association with the PM.

Dabor et al., (2015) studied the influence of corporate governance practices on the company's financial performance in the textile sector of the listed companies working in Pakistan from 2005 to 2014. The results showed that corporate governance has a positive association on the company's performance.

Kobuthi et al., (2018) Researching how to establish the influence of corporate governance on performance-listed companies working at the Nairobi Securities Exchange (NSE), this study found a significant relationship between corporate governance and non-financial performance of the Nairobi-listed company Securities Exchange which confirmed that organizations can improve their performance by implementing good corporate governance, particularly good corporate governance attributes that are important.

Al-hassan et al., (2015) investigates the relationship between the board size and the performance of the Bank (ROA) at registered banks in Saudi over 2007-2012 using samples from 10 registered banks and finds that the board size has a positive relationship with the company's performance but not important. The results showed that the larger board was ineffective in improving financial performance in the context of Bank Arabia.

Teguh Wicaksono and Raharja, (2014) It is known that the Board of directors and audit committees have a positive influence on the increase of return on equity but the size of the board of commissioners has a negative influence. This indicates that the good corporate governance proxy does not affect the profitability of the corporate Governance Perception Index (CGPI) year 2012. Unlike the research conducted by Sarafina \& Saifi, (2017) research on the state-owned enterprises, the independent Board of Commissioners has partially significant effect on Tobins'q.

A study on 28 manufacturing companies registered in Sri Lanka revealed that there was no significant difference between the company's performance between corporate governance practices as the structure of the board's leadership, council committees, council meetings and the proportion of non-executive directors (Achchuthan \& Rajendran, 2013). 
Ineffective good corporate governance is the leading cause of economic crises and failures in various Indonesian companies lately. Effective implementation of good corporate governance can make an important contribution in improving the economic condition and avoiding the occurrence of similar failures in the future.

Based on the contradictions in the results of previous studies, this study reexamined the effect of corporate governance on financial performance.

\section{METHODS}

The data source used in this study is secondary data, this research was conducted in the food and beverage sector manufacturing company listed on the Indonesia Stock Exchange in 2014-2018. The data used in this research is accessed by Indonesian Capital Market Directory. Research time starts from january 2015 - december 2018. Respondents used in this study are the financial reports of food and beverage companies listed on the Indonesia Stock Exchange which are sampled in this research.

The samples in this study were selected using the Purposive sampling method. Data was analyzed using classic assumption tests and hypothesis tests (multiple regression). This study uses quantitative data analysis methods and uses the SPSS version 18 to answer the problems that haveresearch on good corporate governance relations and performance of the company has been carried out, both research using corporate governance assessment index and corporate governance structure.

This research variable there are 2 (two) of independent variables (free) and dependent variables (bound).

\section{Dependent Variable}

The dependent variable that in this study is return on equity (ROE), which is calculated using the following formula:

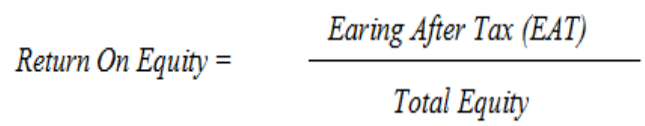

\section{Independent Variable}

\section{Audit Committee}

Is a committee responsible for supervising the company's external audit and is the main contact between the auditor and the company. The Audit committee calculation is the total number of committee members in a company. Audit Committee $=\sum$ Total Audit Committee 


\section{Board of Commissioners}

The proportion of independent commissioners is measured by the number of independent commissioners to the total commissioners in the board of commissioners ' membership (Haat et al. 2008).

Number of Board of Commissioners

Total Independent Board of Commissioners

\section{Board of Directors}

Number of board directors based on the number of directors in the company in the period concerned.

Board of Directors $=\sum$ Total Board of Directors

\section{Debt to Equity Ratio (DER)}

Debt to equity ratio is measured by comparing the amount of use of debt to its own capital owned by the company. Debt to equity ratio can be calculated with the following formula:

$$
\frac{\text { Total Debt }}{\text { Total Capital }}
$$

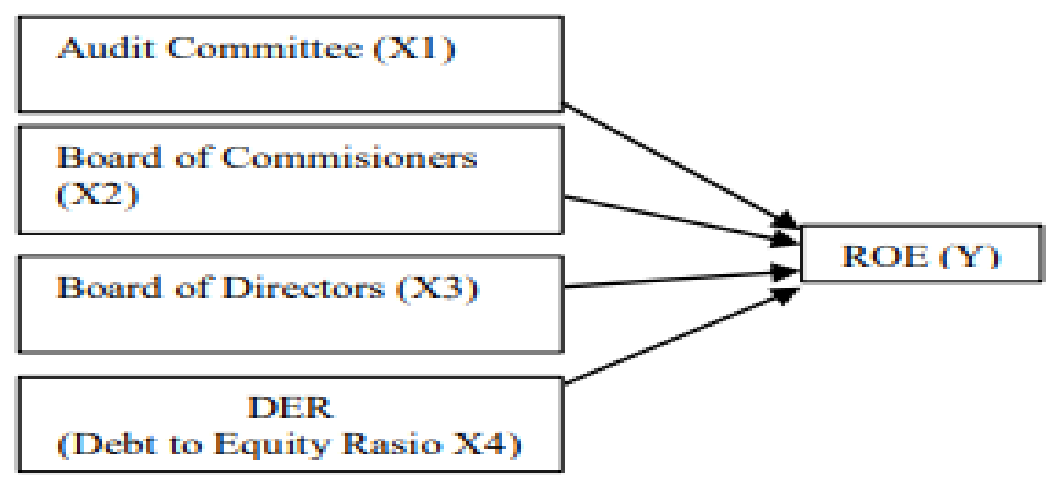

Figure 1. Hypotheses

\section{Hypotheses}

H1: The audit committee affects the company's financial performance.

$\mathrm{H} 2$ : The board of commissioners affects the company's financial performance.

H3: The board of directors affects the company's financial performance.

H4: Debt to equity ratio (DER) affects the company's financial performance. 


\section{RESULTS}

List of companies samples

Tabel 1. List Sample

\begin{tabular}{ccl} 
& \multicolumn{2}{l}{ List of companies samples } \\
\hline No & Code & \multicolumn{1}{c}{ Company Name } \\
\hline 1 & CEKA & Cahaya Kalbar. Tbk. \\
2 & DLTA & PT. Delta Djakarta, Tbk. \\
3 & ICBP & PT. Indofood CBP Sukses Makmur. Tbk. \\
4 & INDF & PT. Indofood Sukses Makmur. Tbk. \\
5 & MLBI & PT. Multi Bintang Indonesia, Tbk. \\
6 & MYOR & PT. Mayora Indah, Tbk. \\
7 & ROTI & PT. Nippon Indosari Corpindo. Tbk. \\
8 & SKBM & PT. Sekar Bumi. Tbk \\
9 & SKLT & PT. Sekar Laut \\
10 & ULTJ & Ultraiaya Milk Industry and Tranding \\
\end{tabular}

\section{Descriptive Statistics}

Tabel 2. Descriptive Statics

\begin{tabular}{|l|r|r|r|r|r|}
\hline & $\mathrm{N}$ & Minimum & Maximum & Mean & Std. Deviation \\
\hline Audit Committee & 50 & 1,00 & 3,00 & 2,8000 &, 45175 \\
Board of & 50 &, 25 &, 67 &, 3831 &, 07756 \\
Commisioners & & & & & \\
Board of Directors & 50 & 3,00 & 10,00 & 5,6600 & 2,30890 \\
DER & 50 &, 00 & 1129,59 & 135,5068 & 315,22224 \\
ROE & 50 &, 68 & 6,89 & 2,6316 & 1,44401 \\
Valid N (listwise) & 50 & & & & \\
\hline
\end{tabular}

Based on the results of the above descriptive test research illustrates that the ROE shows a minimum value of 0.68 and a maximum value of 6.89 with an average of 2.6316 and a standard deviation of 1.4440 . Then for the Audit committee variable minumum value 1 and Maximum value 3 with an average value of 2.8 and standard deviation 0.4517 .

The BOC's Variable indicates a minimum value of 0.25 maximum value of 0.67 with an average of 0.3831 and a standard deviation of 0.7756. Variable Board of Directors shows a minimum value of 3 and a maximum value of 10 for an average value of 5.660 and a standard deviation of 2.308. The Variable DER shows a minimum value of 0 and a maximum value of 1,129.59 and an average value of 135.506 with a standard value of 315.222 deviation. 
Classic Assumption Test

Normality Test

Tabel 3. Normality Test Result

\begin{tabular}{cccc}
\hline Variable & Sig. (2-tailed) & Std & Desc \\
\hline Unstandardized Residual & 0,174 & $>0,05$ & Data Normal \\
\hline
\end{tabular}

Based on the normality test result using One-sample KolmogorovSmirnov Test, it can be seen the significance value is $0094>0.05$, then the result is normal.

Multicolinearity Test

Tabel 4. Test Multicolinearity Test

\begin{tabular}{|c|c|c|c|c|c|}
\hline Variable & Tolerance & Std & VIF & Std & Desc \\
\hline $\mathrm{KA}$ & 0,935 & $>0,10$ & 1,069 & $<10$ & $\begin{array}{c}\text { No } \\
\text { Multicolinearity } \\
\text { No }\end{array}$ \\
\hline DK & 0,975 & $>0,10$ & 1,025 & $<10$ & $\begin{array}{c}\text { Multicolinearity } \\
\text { No }\end{array}$ \\
\hline DD & 0,433 & $>0,10$ & 2,312 & $<10$ & $\begin{array}{c}\text { Multicolinearity } \\
\text { No }\end{array}$ \\
\hline DER & 0,439 & $>0,10$ & 2,276 & $<10$ & Multicolinearity \\
\hline
\end{tabular}

The table above shows that no free variables have a tolerance value of $>0.01$ the same is demonstrated by the VIF value, where the VIF value is $<10$. So it can be concluded that the regression model on this research has no multicholinerality and regression model worth using.

\section{Autocorrelation Test}

Tabel 5. Autocorrelation test Result

\begin{tabular}{cccc}
\hline Durbin - Watson & D1 & Du & Desc \\
\hline 1,822 & 1,38 & 1,72 & No effect of autocholineration \\
\hline
\end{tabular}

Based on the autocorrelation test result above can be known that Durbin Watson value is 1.822 . Since DW tilapia ranged from 1.55 up to 2.46 it can be concluded that there is no autocorrelation problem.

Heteroskedastisity Test

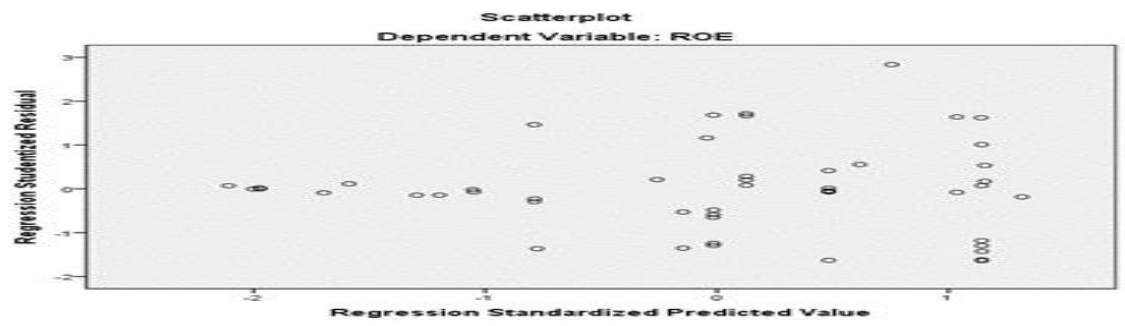

Picture 2. Heteroskedastisity test Results 
The Scatterplot graph can be seen that the data points are scattered above and below or around the 0 , the dots do not accumulate only above or below, the spread of data points does not form a widening wavy pattern then narrowed and widened again, and the spread of the data points is not patterned. It can be concluded that there is no heteroskedastisity on the regression model, so the regression model deserves to be used to predict the dependent variable based on its independent variable input.

\section{Double Linear Regression Test}

A multiple linear regression analysis is a technique through the parameter coefficient to know the magnitude of the variable independent of the dependent variable. Testing can be done by looking at probability values i.e. if the probability (significant) is greater than 0.05 then independent variables have no effect on the dependent variables, likewise otherwise.

Tabel 6. Multiple linear regression test results

\begin{tabular}{cc}
\hline Desc & B \\
\hline Constant & 3,973 \\
Audit Committee (KA) & 0,215 \\
Board of Commissioners (DK) & 0,31 \\
Board of Directors (DD) & $-0,441$ \\
Debt to Equity Ratio (DER) & 0,245 \\
\hline
\end{tabular}

As for the equation of regression above which can be shaped as follows:

$$
\mathrm{Y}=3,973+0,215 \mathrm{KA}+0,31 \mathrm{DK}-0,441 \mathrm{DD}+0,245 \mathrm{DER}
$$

From the equation it can be explained as follows:

The value of constants of 3.973 states that if all independent variables of the Audit Committee (X1), the Board of Commissioners (X2), the Board of Directors (X3) and DER (X4) are considered constant or worth 0 , then the $\mathrm{Y}$ variable is 3.973.

Regression coefficient of Audit Committee (X1) of 0.31 which means if $\mathrm{X} 1$ increase by $1 \%$ then the value of financial performance of the company will increase by 0.31 assuming other factors remain.

Regression coefficient of board of commissioners (x2) of 0.441 which means if $\mathrm{x} 2$ rises $1 \%$ then the company's financial performance will increase by 0.441 assuming other factors remain.

A regression coefficient of the board of directors (x 3 ) of -0.441 which means when $\mathrm{x} 3$ rises $1 \%$ then the company's financial performance tilapia will drop by 0.441 assuming other factors remain.

The coefficient of debt to equity ratio (X4) of 0.245 equal means if $\mathrm{X} 4$ increase $1 \%$ then the value of financial performance of the company will increase by 0.245 assuming the other factors remain. 
Tabel 7. F Test Result

\begin{tabular}{ccccc}
\hline Desc & FHitung & FIabel & Sig & P \\
\hline F Test & 4,383 & 2,76 & 0,004 & $<0,05$ \\
\hline
\end{tabular}

From test $\mathrm{F}$ results can be generated Fcalculate value of 4.484 and significance 0.004 . F table is obtained from table $\mathrm{F}$ at significance level $5 \%$ or 0.05 with DF 1 (total variable -1 ) then the results obtained DF $14-1=3$ and for DF 2 (the amount of data-K) then the result of DF 2 is $50-3=47$. The results obtained for F table DF $1=3$ and $\mathrm{df}$ $2=47$ are 2.20. The results of the test show the value F count $>F$ table $(4.383>2.76)$ and the significance of the < of $0.05(0.004<0.05)$ so that it can be concluded that $\mathrm{HO}$ is rejected while $\mathrm{Ha}$ is accepted which means KA, DK, DD, DER simultaneously affects ROE.

T Test

Table 8. T Test Result

\begin{tabular}{cccccl}
\hline Variable & tamer & t table & Sig. & Std & Dese \\
\hline KA. & 0,510 & 2,000 & 0,612 & 0,05 & Not Significant \\
DK & 0,013 & 2,000 & 0,990 & 0,05 & Not Significant \\
DD & $-4,137$ & 2,000 & 0,150 & 0,05 & Significant \\
DER & 2,765 & 2,000 & 0,008 & 0,05 & Significant \\
\hline
\end{tabular}

H1: Variable audit committee (KA) can be concluded that there is no influence on the financial performance, where the value of significance is greater than 0.05 that is 0.645 then it can be concluded that $\mathrm{H} 1$ is rejected.

$\mathrm{H} 2$ : Variable board of commissioners (DK) can be concluded that there is no influence on the financial performance, where the value of significance is greater than 0.05 that is 0.434 then it can be concluded that $\mathrm{H} 2$ rejected.

H3: Variable board of directors (DD) can be concluded that there is an influence on financial performance, where the value of significance is greater than 0.05 that is 0.022 then it can be concluded that $\mathrm{H} 3$ received.

H4: The Variable debt to equity ratio (DER) can be concluded that there is an influence on financial performance, where the value of significance is less than 0.05 that is 0.001 then it can be concluded that $\mathrm{H} 4$ is accepted.

\section{Coefficient of Determination Test}

Table 9. Coefficient determination test Result

\begin{tabular}{ccc}
\hline Model & Adjusted $\boldsymbol{R}$ Square & Desc \\
\hline 1 & 0,216 & $\begin{array}{c}\text { Independent variables can explain } \\
\text { dependent variables }\end{array}$ \\
\hline
\end{tabular}

P-ISSN: 2655-3651 E-ISSN: 2656-0435

P a g e | 71 
Based on the results of coifisien test determination can be known that the Adjusted R Square of 0.216 or by $21.6 \%$ of the variable Y, can be explained by the variable variable independent audit committee, board of commissioners, board of directors, and DER. As for the rest is $78.4 \%$ (100\%-21.6\%) Described by the explanatory variables or the variables outside of the model used in the study.

\section{DISCUSSION}

The first hypothesis is that the Audit Committee has an effect on financial performance and the test results show that the audit committee has no significant effect on financial performance. Members of the audit committee lack high integrity, ability, knowledge, and experience in accordance with his education, as well as being able to communicate well or audit committee members who are educational background from non-accounting or financial so that knowledge and understanding of financial statements are less professional. It can be noted that the average size of the company's Audit committee is 3 people, meaning that most companies have the same number of members of the Audit Committee of 3 people. This is likely to cause the Audit committee to have no effect on the company's performance and value.

Hypothesis 2 shows that the large amount of the Board of Commissioners does not guarantee against the performance of the company which means that it is not certain that the number of commissioners will show no fraud in the company's financial statements. In addition, with the board of commissioners can not prevent the manager to maximize the interests of the company so as to achieve the company's targets. There is a view that the independence of the greater board of commissioners is better to improve the company's performance because they have a wider range of capabilities to help make better decisions. However, there is a possibility that the number of the board of commissioners is much less effective. when the number of BOC members becomes too many, coordination will become increasingly difficult, and especially problematic in making decision making.

Hypothesis 3 that the board of directors affects financial performance and results shows that the board of directors has a significant effect on financial performance. this indicates that the number of board of directors will be able to increase the financial performance of the company.

Hypothesis 4 is that debt to equity ratio has an effect on financial performance and the test results show that debt to equity ratio has significant effect on financial performance. Means the company in the face of competition required a funding used to meet the needs. Sources of funds can be obtained from within the company (internal) and outside the company (external). The comparison between own capital and debt should be balanced because increased debt can affect 
a large corporate profit that reflects the company's ability to fulfill all its obligations, indicated by some parts of its own capital used to pay for all its obligations, as the greater the use of debt is the greater its obligation.

\section{CONCLUSION}

This research aims to test the influence of the audit committee, board of commissioners, board of directors, and debt to quity ratio to the financial performance (ROE) with the data used is the manufacturing company of food and beverage sector listed on the Indonesia Stock Exchange (IDX). The data used in this research is based on an annual report within a five-year period starting from 2014-2018 with a total of 50 financial reporting data from 10 companies. The sampling techniques in this study are purposive sampling and analysis of data used i.e. multiple linear regression analyses with data processing using SPSS applications.

Based on the research and hypothesis tests that have been conducted it can be concluded that the debt equity ratio (DER) and the board of directors are influential in the financial performance because the value of significance is greater than the standard of significance, because the board of directors will provide benefits to the company and ensure the creation of good relations with outside parties, then companies that have little debt by utilizing their own capital for the financing of the company will make financial performance will also be good with management of good financial management. The audit committee, the board of commissioners has no effect on the company's financial performance, as the effectiveness of the audit committee and board of commissioners is not based on profit, capital and total assets, but rather the quality of its manufacturing resources.

\section{RECOMMENDATION}

Further research can add other variables such as leverage, price book value, etc. in order to get the adjusted value of R square better. And further research can be done using other industrial sectors such as banking, mining, or any other sector that can be assigned to research, in order to get different results or conclusions.

\section{REFERENCES}

Achchuthan, S., \& Rajendran, K. (2013). Corporate governance practices and working capital management efficiency: special reference to listed manufacturing companies in Sri Lanka. Information \& Knowledge Management, 3(2).

Adekunle, S. A., \& Aghedo, E. M. (2014). Corporate governance and financial performance of selected quoted companies in Nigeria. European Journal of Business and Management, 6(9).

Dabor, A. O., Isiavwe, D. T., Ajagbe, M. A., \& Oke, O. A. (2015). Impact of corporate governance on firm performance in Nigeria. 
International Journal of Economics, Commerce and Management. United Kingdom, 3(6), 634-653.

Darmawati, D., Khomsiyah, K., \& Rahayu, R. G. (2005). Hubungan Corporate Governance dan kinerja perusahaan. The Indonesian Journal of Accounting Research, 8(1).

Dzingai, I., \& Fakoya, M. B. (2017). Effect of corporate governance structure on the financial performance of Johannesburg Stock Exchange (JSE)-listed mining firms. Sustainability, 9(6), 867.

Fuenzalida, D., Mongrut, S., Arteaga, J. R., \& Erausquin, A. (2013). Good corporate governance: Does it pay in Peru? Journal of Business Research, 66(10), 1759-1770.

Gitman, L. J., \& Zutter, C. J. (2012). Principles of Managerial Finance. 13e. Aufl., Boston Ua.

Hardikasari, E. (2011). Pengaruh Penerapan Corporate Governance Terhadap Kinerja Keuangan Pada Industri Perbankan Yang Terdaftar Di Bursa Efek Indonesia (BEI) Tahun 2006-2008. Universitas Diponegoro, Semarang.

Homaidi, E. A. Al, Almaqtari, F. A., Ahmad, A., \& Tabash, M. I. (2019). Impact of corporate governance mechanisms on financial performance of hotel companies: Empirical evidence from India. African Journal of Hospitality, Tourism and Leisure, $8(2), 1-21$.

Kobuthi, E., K'Obonyo, P., \& Ogutu, M. (2018). Corporate Governance and Performance of Firms Listed on the Nairobi Securities Exchange.

Munisi, G., \& Randøy, T. (2013). Corporate governance and company performance across Sub-Saharan African countries. Journal of Economics and Business, 70, 92-110.

Nur, H., \& Tirta, M. Y. (2011). Pengaruh Good Corporate Governance terhadap Kinerja Keuangan Bank Umum Syariah. Universitas Jember.

Riyadi, Y. (2012). Safeguard Lindungi Produk Lokal. Tribun News (http://batam. tribunnews. com/2012/07/18/safeguardlindungi ....

Sarafina, S., \& Saifi, M. (2017). Pengaruh good corporate governance terhadap kinerja keuangan dan nilai perusahaan (Studi pada Badan Usaha Milik Negara (BUMN) yang terdaftar di Bursa Efek Indonesia periode 2012-2015). Jurnal Administrasi Bisnis, 50(3), 108-117.

Suranta, E., \& Merdistuti, P. P. (2004). Income Smoothing, Tobin's Q, Agency Problems dan Kinerja Perusahaan. Simposium Nasional Akuntansi VII, 340-357. 
Uchida, S., Ahmed, S. U., \& Aabed, A. (2011). Corporate Governance and Firm Performance in the Financial Sector. Annual Review of Southeast Asian Studies, 52, 107-115. 